\title{
The relationship between COVID-19's severity and ischemic stroke: a systematic review and meta-analysis
}

\author{
Yue Lu ${ }^{1} \cdot$ Jie-ji Zhao ${ }^{1} \cdot$ Meng-fan Ye ${ }^{1} \cdot$ Hong-mei $\mathrm{Li}^{1} \cdot$ Fei-rong Yao ${ }^{2} \cdot$ Yan Kong $^{1} \cdot$ Zhuan Xu $^{1}$ (D) \\ Received: 28 January 2021 / Accepted: 28 April 2021 / Published online: 5 May 2021 \\ (C) Fondazione Società Italiana di Neurologia 2021
}

\begin{abstract}
Objective We aim to determine the risk of acute ischemic stroke in patients with severe and non-severe coronavirus disease 2019 (COVID-19).

Methods A literature search was conducted in the PubMed, Embase, Web of Science, and Cochrane Library databases until October 28, 2020. Studies covering COVID-19's severity classification data and COVID-19 patients with acute ischemic stroke were included. Two independent evaluators extracted data, and the random effects model was used to calculate the risk ratios (RR) and 95\% confidence interval (95\% CI) of acute ischemic stroke associated with COVID-19's severity.

Results A total of 8 studies were included, involving 5266 patients. Among all COVID-19 patients, the total incidence of ischemic stroke was $1.76 \%$ (95\% CI: 0.82-3.01). Severe patients have an increased risk of acute ischemic stroke compared with non-severe patients ( $\left.\mathrm{RR}=3.53,95 \% \mathrm{CI}: 2.06-6.07, P<0.0001 ; I^{2}=12 \%\right)$. This association was also observed when COVID19 's severity was defined by clinical parameters (RR $2.91,95 \%$ CI: $1.17-7.26, P=0.02 ; I^{2}=29 \%$ ) and the need for intensive care (RR 4.47, 95\% CI: $2.40-8.31, P<0.0001 ; I^{2}=0 \%$ ).

Conclusions This meta-analysis shows that the severe course of COVID-19 is associated with an increased risk of acute ischemic stroke.
\end{abstract}

Keywords Meta-analysis · COVID-19 · Severity $\cdot$ Ischemic stroke

\section{Introduction}

Severe acute respiratory syndrome coronavirus 2 (SARS$\mathrm{CoV}-2$ ) infection is associated with changes in blood coagulation, and it increases the risk of thromboembolism (including arterial and venous embolism). These complications may be mediated by systemic inflammatory injury of vascular endothelial cells, platelet activation, and stasis [1, 2]. Although

Yue Lu and Jie-ji Zhao contributed equally to this work.

Fei-rong Yao

67898526@163.com

Yan Kong

kong0919@163.com

$\triangle$ Zhuan Xu

xuzhuan772@126.com

Yue $\mathrm{Lu}$

luyue1216@163.com

Jie-ji Zhao

535054402@qq.com the incidence of deep venous thrombosis and pulmonary embolism is high in many coronavirus disease 2019 (COVID-19) cohorts, it is not clear how acute ischemic stroke occurs in this disease [3, 4]. Recent reviews or meta-analysis about the neurological manifestations of COVID-19 suggest that a majority of COVID-19 patients with stroke show ischemic stroke, while a few patients show hemorrhagic stroke or cerebral venous thrombosis [5-7]. Almost all patients have potential risk
Meng-fan Ye

1946033387@qq.com

Hong-mei Li

1030390843@qq.com

1 Department of Neurology, The First Affiliated Hospital of Soochow University, Suzhou, China

2 Department of Radiology, The First Affiliated Hospital of Soochow University, Suzhou, China 
factors for stroke, including diabetes, hyperlipidemia, hypertension, and previous history of cerebrovascular disease [5].

Recently, some articles about COVID-19 have expounded the relationship between acute ischemic stroke and COVID$19[8,9]$. Siepmann et al. [10] recently conducted a multicenter study and meta-analysis of 741 patients with COVID-19. They found that the total stroke rate was $2.9 \%$ and that patients with severe COVID-19 had an increased risk of acute ischemic stroke compared with patients with non-severe COVID. However, this meta-analysis included only three studies, which is too few. Therefore, we conducted a systematic review and meta-analysis to explore the possible association between SARS-CoV-2 infection and acute ischemic stroke.

\section{Methods}

\section{Literature search strategy}

A literature search was conducted in the PubMed, Embase, Web of Science, and Cochrane Library databases until October 28, 2020. Studies covering COVID-19's severity classification data and COVID-19 patients with acute ischemic stroke were included. The search terms were as follows: "Coronavirus," "COVID 19," "2019-nCoV," "SARS-CoV2," "stroke," "cerebrovascular," "transient ischemic attack," "cerebral infarction," "brain infarction," "cerebral ischemia."

\section{Selection criteria}

The studies were included according to the following criteria: (1) randomized or non-randomized observational study of at least five adult patients diagnosed with COVID-19 by molecular RT-PCR; (2) available data on the incidence of ischemic stroke in COVID-19 patients; and (3) classification of the severity of COVID-19 patients mentioned. We excluded all case series, case reports, letters, editorial, comments, conference abstracts, and studies including only cerebral hemorrhage and cerebral venous thrombosis.

\section{Data extraction and quality assessment}

Two reviewers independently accessed all retrieved articles according to screening titles, abstracts, and full texts. If there were differences between the two reviewers on the results of literature retrieval, the opinions of other coauthors would be consulted and resolved through consensus. We obtained data from each study including authors, publication year, study types, countries, sample size, age, sex, observational period, definition of COVID-19 severity, and acute ischemic stroke incidence in COVID-19 patients. The Newcastle-Ottawa scale (NOS) was used to assess the quality of the included studies [11]. The NOS scores of 1 to 3,4 to 6 , and 7 to 9 were judged for low, moderate, and high quality of studies, respectively. Two investigators independently conducted the quality assessment, and the differences were resolved by consensus.

\section{Statistical analysis}

A comprehensive dichotomy of severity was used in our main analysis, which included all severity results reported in each study comprising severity based on clinical parameters [12-16] and the need for intensive care (ICU) and non-ICU. If the included studies divide the severity outcomes into two or more categories based on clinical parameters (e.g., mild, moderate, severe, critical), these are classified as non-severe (including mild and moderate) and severe (including severe and critical) categories. Therefore, in our main analysis, we divided all patients into severe or non-severe COVID-19 according to the classification used in each study included.

We performed this meta-analysis using $\mathrm{R}$ software. The variance-stabilizing double arcsine transformation was used in all proportion analyses. The random effects model was used to calculate the outcomes through pooled proportion metaanalysis. The Mantel-Haenszel formula is used to calculate the binary variable to calculate the risk ratio (RR) and report it with its $95 \%$ confidence interval (CI). $P<0.05$ indicated statistical significance. $I^{2}$ statistics were used to record and evaluate statistical heterogeneity $\left(I^{2}\right.$ value of $0-40 \%$ indicated no or low heterogeneity, 30-60\% indicated moderate heterogeneity, 50-90\% indicated substantial heterogeneity, and 75$100 \%$ indicated considerable heterogeneity). Publication bias was evaluated using a funnel plot.

\section{Results}

\section{Characteristics of included studies}

The database search identified 2391 relevant studies: 890 from PubMed, 20 from the Cochrane library, 880 from Embase, and 601 from Web of Science. Among these studies, 1339 studies were excluded due to repetition, and 958 studies were excluded after preliminary screening of titles and abstracts. After reading the full text, 86 articles were excluded. Finally, 5266 patients from 8 studies were included in the final review and meta-analysis [9, 10, 12, 17-21]. The systematic screening and selection process are depicted in Fig. 1. The characteristics of the included studies are shown in Table 1. The included studies consisted of cohorts from China, Italy, Germany, the USA, Spain, and Pakistan and were designed for descriptive observations.

In these studies, the severity of COVID-19 was clinically defined according to the necessity of intensive care, the 
Table 1 Study characteristics of included published studies

\begin{tabular}{|c|c|c|c|c|c|c|}
\hline Study & Location & Study design & $\begin{array}{l}\text { Severity } \\
\text { outcomes }\end{array}$ & $\begin{array}{l}\text { Study size } \\
(n)\end{array}$ & $\begin{array}{l}\text { Acute stroke, } \\
n(\%)\end{array}$ & Observational period \\
\hline Li et al., 2020 [17] & Wuhan, China & $\begin{array}{l}\text { Single center, } \\
\text { retrospective }\end{array}$ & $\begin{array}{l}\text { Severe vs. } \\
\quad \text { non-severe }\end{array}$ & 92 vs. 127 & $\begin{array}{c}8 \text { ( } 8.7) \text { vs. } 2 \\
(1.6)\end{array}$ & $\begin{array}{l}\text { 16 January } 2020-19 \\
\text { February } 2020\end{array}$ \\
\hline $\begin{array}{l}\text { Lodigiani et al., } 2020 \\
\text { [21] }\end{array}$ & Milan, Italy & $\begin{array}{l}\text { Single center, } \\
\text { retrospective }\end{array}$ & ICU vs. non-ICU & 61 vs. 327 & $\begin{array}{l}3 \text { (4.9) vs. } 6 \\
(1.8)\end{array}$ & $\begin{array}{l}13 \text { February } 2020-10 \text { April } \\
2020\end{array}$ \\
\hline $\begin{array}{l}\text { Siepmann et al., } 2020 \\
\text { [10] }\end{array}$ & Saxony, Germany & $\begin{array}{l}\text { Multicenter, } \\
\text { retrospective }\end{array}$ & $\begin{array}{l}\text { Severe vs. } \\
\text { non-severe }\end{array}$ & 119 vs. 46 & $\begin{array}{c}6(5.0) \text { vs. } 1 \\
(2.2)\end{array}$ & $\begin{array}{l}1 \text { March } 2020-30 \text { April } \\
2020\end{array}$ \\
\hline $\begin{array}{l}\text { Romero-Sánchez et al., } \\
2020 \text { [9] }\end{array}$ & $\begin{array}{l}\text { Castilla-La Mancha, } \\
\text { Spain }\end{array}$ & $\begin{array}{l}\text { Multicenter, } \\
\text { retrospective }\end{array}$ & $\begin{array}{l}\text { Severe vs. } \\
\text { non-severe }\end{array}$ & $\begin{array}{c}329 \text { vs. } \\
512\end{array}$ & $\begin{array}{l}4 \text { (1.2) vs. } 7 \\
(1.4)\end{array}$ & 1 March 2020-1 April 2020 \\
\hline $\begin{array}{l}\text { Merkler et al., } 2020 \\
{[20,22]}\end{array}$ & New York, USA & $\begin{array}{l}\text { Multicenter, } \\
\text { retrospective }\end{array}$ & ICU vs. non-ICU & $\begin{array}{r}474 \text { vs. } \\
1442\end{array}$ & $\begin{array}{l}19(4.0) \text { vs. } 12 \\
(0.8)\end{array}$ & 4 March 2020-2 May 2020 \\
\hline Liotta et al., 2020 [12] & Chicago, USA & $\begin{array}{l}\text { Multicenter, } \\
\text { retrospective }\end{array}$ & $\begin{array}{l}\text { Severe vs. } \\
\text { non-severe }\end{array}$ & $\begin{array}{c}134 \text { vs. } \\
375\end{array}$ & $\begin{array}{l}5(3.7) \text { vs. } 2 \\
(0.5)\end{array}$ & 5 March 2020-6 April 2020 \\
\hline Piazza et al., 2020 [19] & Boston, USA & $\begin{array}{l}\text { Multicenter, } \\
\text { retrospective }\end{array}$ & ICU vs. non-ICU & $\begin{array}{c}170 \text { vs. } \\
944\end{array}$ & $1(0.6)$ vs. 0 & $\begin{array}{l}13 \text { March 2020-03 April } \\
2020\end{array}$ \\
\hline Makda et al., 2020 [18] & Karachi, Pakistan & $\begin{array}{l}\text { Single center, } \\
\text { retrospective }\end{array}$ & $\begin{array}{l}\text { Severe vs. } \\
\text { non-severe }\end{array}$ & 62 vs. 52 & $3(4.8)$ vs. 0 & April 2020-July 2020 \\
\hline
\end{tabular}

USA the United States, ICU intensive care unit. Results are expressed as number (column \%), mean $\pm \mathrm{SD}$, or median (interquartile range)

${ }^{a}$ According to the American Thoracic Society guidelines for community-acquired pneumonia

${ }^{\mathrm{b}}$ According to National Health Commission of the People's Republic of China. Chinese Management Guideline for COVID-19 (version 7.0)

${ }^{c}$ According to the 2007 Infectious Diseases Society of America/American Thoracic Society criteria

${ }^{\mathrm{d}}$ According to the need for mechanical ventilation during hospitalization

e According to the Pakistan's national guidelines for the management of COVID-19

American Thoracic Society guidelines for communityacquired pneumonia[13], the Chinese Management Guidance for COVID-19 Diagnosis and Treatment (7th version) [14], the 2007 Infectious Diseases Society of America/American Thoracic Society criteria [15], the need for mechanical ventilation during hospitalization [12], and the Pakistan's national guidelines for the management of COVID-19 [16].

\section{Quantitative data synthesis}

Among all COVID-19 patients, the total incidence of ischemic stroke was $1.76 \%$ (95\% CI: 0.82-3.01). According to the severity of the disease, the total stroke rate of patients with severe COVID-19 was $3.37 \%$ (95\% CI: $1.74-5.44$ ), and that of patients with non-severe COVID-19 was $0.61 \%$ (95\% CI: $0.08-1.45)$.

Severe patients had an increased risk of acute ischemic stroke than non-severe patients when using a compound dichotomy that included all severity results included in each study report (RR $=3.53,95 \%$ CI: $2.06-6.07, P<0.0001 ; I^{2}$ $=12 \%$; Fig. 2a). This association was also observed when COVID-19's severity was defined by clinical parameters (RR 2.91, 95\% CI: 1.17-7.26, $P=0.02 ; I^{2}=29 \%$; Fig. $2 b$ ) and the need for intensive care (RR 4.47, 95\% CI: 2.40-8.31, $P<0.0001 ; I^{2}=0 \%$; Fig. $2 \mathrm{c}$ ).

\section{Quality analysis of studies and assessment of publication bias}

As shown in Table 2, the quality of the eight included studies according to the NOS was moderate to high with NOS scores ranging from 5 to 7 . Through the visual observation of the funnel plot (Fig. 3), both the studies plotted near the average, and the studies more distant from the average showed symmetry, so the distribution does not imply publication bias.

\section{Discussion}

Through a systematic review and meta-analysis of 8 studies, 5266 COVID-19 patients with ischemic stroke were identified. The main findings of this study are as follows: (1) the total incidence of ischemic stroke was $1.76 \%$ in COVID-19 patients; and (2) the severe course of COVID-19's disease is associated with an increased risk of acute ischemic stroke.

For acute ischemic stroke, infection is an important risk factor, especially systemic upper respiratory disease [23, 24]. It is reported that patients with COVID-19 are about 7 times more likely to suffer from acute ischemic stroke during emergency department visits or hospitalization than patients with influenza [22]. Thus, SARS-CoV-2 may be a higher risk factor for acute ischemic stroke than other classic respiratory infections such as influenza [21]. 


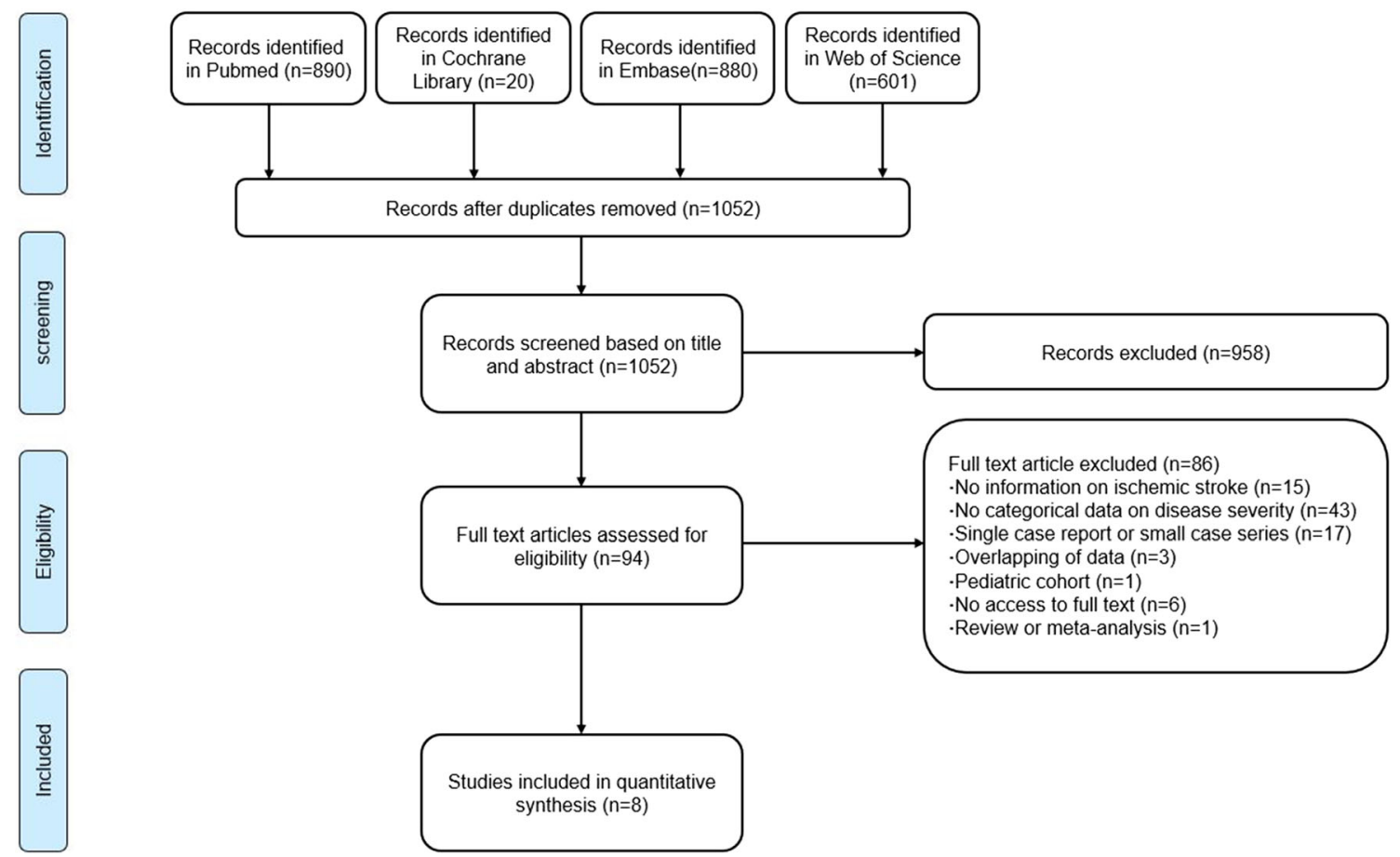

Fig. 1 Flow diagram of the publication search and selection process.

Fig. 2 Forest plots illustrating associations of ischemic stroke and COVID-19's severity among included studies: (a) composite severity outcome subsuming all definitions of severity as reported by included studies; (b) severity by grading of clinical parameters; (c) severity by whether patients required intensive care. a
Study

Li et al., 2020

Lodigiani et al., 2020

Romero-Sánchez et al., 2020

Siepmann et al., 2020

Merkler et al., 2020

Liotta et al., 2020

Piazza et al., 2020

Makda et al., 2020

Random effects model Heterogeneity: $I^{2}=12 \%, \tau^{2}=0.0762, \delta=0.3^{14}$

Risk Ratio

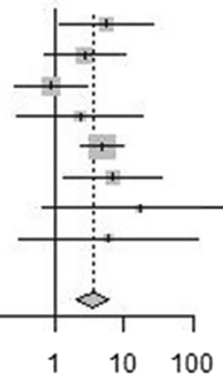

b

Study

Li et al., 2020

Romero-Sánchez et al., 2020

Siepmann et al., 2020

Liotta et al., 2020

Makda et al., 2020

Random effects model Heterogeneity: $I^{2}=29 \%, \tau^{2}=0.3127, p=0.23$
RR $\quad 95 \%-\mathrm{Cl}$ Weight

$5.52[1.20 ; 25.40] 11.2 \%$

$2.68[0.69 ; 10.43] \quad 13.7 \%$

$0.89[0.26 ; 3.01] 16.4 \%$

$2.32[0.29 ; 18.74] \quad 6.3 \%$

$4.82[2.36 ; 9.85] \quad 36.4 \%$

$7.00[1.37 ; 35.63] \quad 10.0 \%$

$16.62[0.68 ; 406.26] \quad 2.8 \%$

$5.88[0.31 ; 111.27] \quad 3.3 \%$

$3.53[2.06 ; 6.07] 100.0 \%$
C

\section{Study}

Lodigiani et al., 2020

Merkler et al., 2020

Piazza et al., 2020

Random effects model Heterogeneity: $I^{2}=0 \%, \tau^{2}=0,0=0.54$ $0.01 \quad 0.1$
Risk Ratio
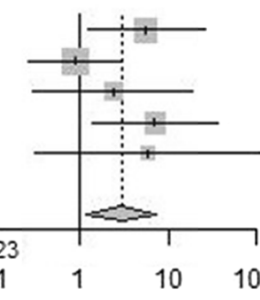

$5.52[1.20 ; 25.40] 23.7 \%$

$0.89 \quad[0.26 ; 3.01] 31.1 \%$

$2.32[0.29 ; 18.74] \quad 15.0 \%$

$7.00 \quad[1.37 ; 35.63] 21.7 \%$

$5.88[0.31 ; 111.27] \quad 8.5 \%$

$2.91 \quad[1.17 ; 7.26] 100.0 \%$
$2.68[0.69 ; 10.43] 20.9 \%$

$4.82 \quad[2.36 ; 9.85] \quad 75.3 \%$

$16.62[0.68 ; 406.26] \quad 3.8 \%$

$4.47[2.40 ; 8.31] 100.0 \%$ 
Table 2 Quality assessment of included studies

\begin{tabular}{|c|c|c|c|c|}
\hline Study & Selection & Comparability & Outcome & Overall \\
\hline Li et al., 2020 [17] & $4^{*}$ & 0 & $2^{*}$ & $6^{*}$ \\
\hline Lodigiani et al., 2020 [21] & $3 *$ & 0 & $2^{*}$ & $5 *$ \\
\hline Siepmann et al., 2020 [10] & $3 *$ & 0 & $2^{*}$ & $5^{*}$ \\
\hline Romero-Sánchez et al., 2020 [9] & $4^{*}$ & 0 & $2^{*}$ & $6^{*}$ \\
\hline Merkler et al., $2020[20,22]$ & $3 *$ & 0 & $2^{*}$ & $5 *$ \\
\hline Liotta et al., 2020 [12] & $4 *$ & 0 & $2^{*}$ & $6^{*}$ \\
\hline Piazza et al., 2020 [19] & $4^{*}$ & 0 & $2^{*}$ & $6^{*}$ \\
\hline Makda et al., 2020 [18] & $3 *$ & $2 *$ & $2 *$ & $7 *$ \\
\hline
\end{tabular}

*Number of stars awarded for each category

The exact mechanism by which COVID-19 increases the risk of acute stroke is not known. Previous studies have shown that the hypercoagulable state caused by COVID-19 is mediated by the increase of prethrombotic factors, immobilizationrelated stagnation and endothelial injury, or through direct viral invasion of endothelial cells by acute systemic inflammatory mediators such as interleukin-6 [25, 26]. COVID-19 has been reported to increase D-dimer levels and to produce antiphospholipid antibodies and other markers of hypercoagulability $[27,28]$. In one of the first published cohort studies, compared with non-ICU patients, 41 patients admitted to a hospital in Wuhan with COVID-19 had elevated D-dimer levels in ICU patients [29]. Guan et al. analyzed the data of 1099 patients in 552 hospitals in China, of which $59.6 \%$ of the severe patients had higher levels of D-dimer, while fewer (43.2\%) of the non-severe patients had elevated levels of Ddimer [30]. It was previously reported that D-dimer $>1 \mathrm{mg} / \mathrm{mL}$ was a risk factor for death and severe COVID-19 [31, 32]. Other reports show that C-reactive protein $>200 \mathrm{mg} / \mathrm{L}$ and D-dimer $>2.5 \mathrm{mg} / \mathrm{mL}$ are related to COVID-19's critical illness, which may be related to high inflammatory state and hypercoagulable state [33]. In addition, critically ill patients may be in a particularly dangerous state due to systemic inflammatory response syndrome accompanied by thrombosis (thrombotic inflammation), hypoxia, and hypotension.

It will be challenging to determine the true incidence of ischemic stroke in COVID-19 patients. Firstly, it is difficult to detect signs of ischemic stroke in severe COVID-19
Fig. 3 Assessment of publication bias. Visual inspection of funnel plot is not indicative of publication bias.

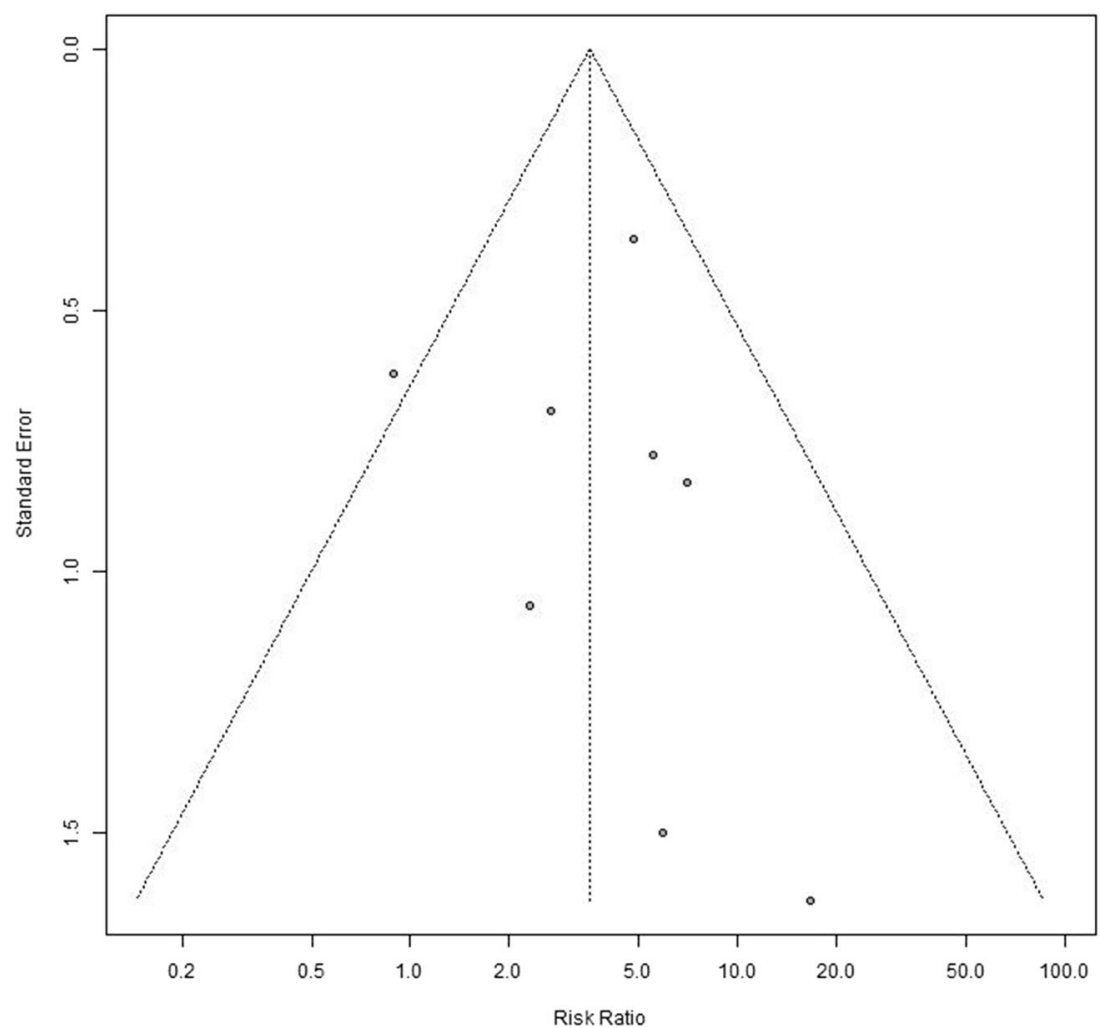


patients with frequent intubation and severe sedation. Decreased awareness is reported to be a risk factor for missing stroke in the emergency room [34]. Secondly, the role of different demographics and ethnicity of patients with COVID-19 in affecting the incidence of acute ischemic stroke remains uncertain. Thirdly, certain countries may also be limited by detection capacity, leading to underreporting of new coronary pneumonia cases, thereby overestimating the incidence of acute ischemic stroke [35]. Fourthly, reluctance to go to the hospital and social distancing policies can also lead to underreporting of mild strokes in mild or asymptomatic COVID-19 patients [36]. It is challenging to determine the true incidence of ischemic stroke in COVID-19 patients, so more research is needed to prove it.

There are still some important limitations in our research. First, our study is limited by the differences in the definition of COVID-19's severity in different studies. However, the result of the analysis using a composite dichotomized outcome is consistent with the results of the application of clinical parameters and the need for intensive care. Second, the sample size of the systematic review may still be limited because it covered a short period of time, and more research is needed.

\section{Conclusion}

The data we have collected from the published literature show that the severe course of COVID-19 is associated with an increased risk of acute ischemic stroke, which highlights the need for clinical neuromonitoring in COVID-19 patients. What is more, further research on its potential pathophysiology is also in demand.

Author contribution Study concept and study design: YL and JJZ. Literature searching and initial records screening: YL and JJZ. Data extraction and interpretation: MFY and HML. Statistical analysis and manuscript drafting: YL and JJZ. Critical revision of manuscript: FRY, YK, and ZX. All the authors read and approved the final version of the manuscript for publication.

\section{Declarations}

Ethics approval Not applicable.

Conflict of interest The authors declare no competing interests.

Informed consent None.

\section{References}

1. Bikdeli B, Madhavan MV, Jimenez D, Chuich T, Dreyfus I, Driggin E, Nigoghossian C, Ageno W, Madjid M, Guo Y, Tang LV, Hu Y, Giri J, Cushman M, Quere I, Dimakakos EP, Gibson
CM, Lippi G, Favaloro EJ, Fareed J, Caprini JA, Tafur AJ, Burton JR, Francese DP, Wang EY, Falanga A, Mc Lintock C, Hunt BJ, Spyropoulos AC, Barnes GD, Eikelboom JW, Weinberg I, Schulman S, Carrier M, Piazza G, Beckman JA, Steg PG, Stone GW, Rosenkranz S, Goldhaber SZ, Parikh SA, Monreal M, Krumholz HM, Konstantinides SV, Weitz JI, Lip GYH, Global Covid-19 Thrombosis Collaborative Group EbtINE, the Iua SbtESCWGoPC, Right Ventricular F (2020) COVID-19 and thrombotic or thromboembolic disease: implications for prevention, antithrombotic therapy, and follow-up: JACC state-of-the-art review. J Am Coll Cardiol 75(23):2950-2973. https://doi.org/10. 1016/j.jacc.2020.04.031

2. Madjid M, Safavi-Naeini P, Solomon SD, Vardeny O (2020) Potential effects of coronaviruses on the cardiovascular system: a review. JAMA Cardiol 5(7):831-840. https://doi.org/10.1001/ jamacardio.2020.1286

3. Cui S, Chen S, Li X, Liu S, Wang F (2020) Prevalence of venous thromboembolism in patients with severe novel coronavirus pneumonia. J Thromb Haemost 18(6):1421-1424. https://doi.org/10. 1111 jth. 14830

4. Tang N, Li D, Wang X, Sun Z (2020) Abnormal coagulation parameters are associated with poor prognosis in patients with novel coronavirus pneumonia. J Thromb Haemost 18(4):844-847. https:// doi.org/10.1111/jth.14768

5. Fatima N, Saqqur M, Qamar F, Shaukat S, Shuaib A (2020) Impact of COVID-19 on neurological manifestations: an overview of stroke presentation in pandemic. Neurol Sci 41(10):2675-2679. https://doi.org/10.1007/s10072-020-04637-6

6. Favas TT, Dev P, Chaurasia RN, Chakravarty K, Mishra R, Joshi D, Mishra VN, Kumar A, Singh VK, Pandey M, Pathak A (2020) Neurological manifestations of COVID-19: a systematic review and meta-analysis of proportions. Neurol Sci 41(12):3437-3470. https://doi.org/10.1007/s10072-020-04801-y

7. Desai I, Manchanda R, Kumar N, Tiwari A, Kumar M (2021) Neurological manifestations of coronavirus disease 2019: exploring past to understand present. Neurol Sci 42(3):773-785. https://doi. org/10.1007/s10072-020-04964-8

8. Mao L, Jin H, Wang M, Hu Y, Chen S, He Q, Chang J, Hong C, Zhou Y, Wang D, Miao X, Li Y, Hu B (2020) Neurologic manifestations of hospitalized patients with coronavirus disease 2019 in Wuhan, China. JAMA Neurol 77(6):683-690. https://doi.org/10. 1001/jamaneurol.2020.1127

9. Romero-Sanchez CM, Diaz-Maroto I, Fernandez-Diaz E, SanchezLarsen A, Layos-Romero A, Garcia-Garcia J, Gonzalez E, Redondo-Penas I, Perona-Moratalla AB, Del Valle-Perez JA, Gracia-Gil J, Rojas-Bartolome L, Feria-Vilar I, Monteagudo M, Palao M, Palazon-Garcia E, Alcahut-Rodriguez C, SopelanaGaray D, Moreno Y, Ahmad J, Segura T (2020) Neurologic manifestations in hospitalized patients with COVID-19: the ALBACOVID registry. Neurology 95(8):e1060-e1070. https:// doi.org/10.1212/WNL.0000000000009937

10. Siepmann T, Sedghi A, Simon E, Winzer S, Barlinn J, de With K, Mirow L, Wolz M, Gruenewald T, Schroettner P, von Bonin S, Pallesen LP, Rosengarten B, Schubert J, Lohmann T, Machetanz J, Spieth P, Koch T, Bornstein S, Reichmann H, Puetz V, Barlinn K (2020) Increased risk of acute stroke among patients with severe COVID-19: a multicenter study and meta-analysis. Eur J Neurol 28: 238-247. https://doi.org/10.1111/ene.14535

11. Wells GASB, O'Connell D, Peterson J, Welch V, Losos M, Tugwell P (2019) The Newcastle-Ottawa Scale (NOS) for assessing the quality if nonrandomized studies in meta-analyses. The Ottawa Hospital Research Institute. http://www.ohri.ca/ programs/clinical_epidemiology/oxford.htm

12. Liotta EM, Batra A, Clark JR, Shlobin NA, Hoffman SC, Orban ZS, Koralnik IJ (2020) Frequent neurologic manifestations and encephalopathy-associated morbidity in Covid-19 patients. Ann 
Clin Transl Neurol 7(11):2221-2230. https://doi.org/10.1002/acn3. 51210

13. Metlay JP, Waterer GW, Long AC, Anzueto A, Brozek J, Crothers K, Cooley LA, Dean NC, Fine MJ, Flanders SA, Griffin MR, Metersky ML, Musher DM, Restrepo MI, Whitney CG (2019) Diagnosis and treatment of adults with community-acquired pneumonia. an official clinical practice guideline of the American Thoracic Society and Infectious Diseases Society of America. Am J Respir Crit Care Med 200(7):e45-e67. https://doi.org/10.1164/ rccm.201908-1581ST

14. National Health Commission (2020) Chinese clinical guidance for COVID-19 pneumonia diagnosis and treatment (7th edition). http:// kjfy.meetingchina.org/msite/news/show/cn/3337.html. Accessed: October 28, 2020

15. Mandell LA, Wunderink RG, Anzueto A, Bartlett JG, Campbell GD, Dean NC, Dowell SF, File TM Jr, Musher DM, Niederman MS, Torres A, Whitney CG, Infectious Diseases Society of A, American Thoracic S (2007) Infectious Diseases Society of America/American Thoracic Society consensus guidelines on the management of community-acquired pneumonia in adults. Clin Infect Dis 44(Suppl 2):S27-S72. https://doi.org/10.1086/511159

16. Ministry of National Health Services: clinical management guideline for COVID-19 infections (2020) http://covid.gov.pk/ guidelines/pdf $/ 20200402 \% 20$ Clinical $\% 20$ Management $\%$ 20Guidelines\%20for\%20COVID-19\%20infections_1201.pdf. Accessed: October 28, 2020

17. Li Y, Li M, Wang M, Zhou Y, Chang J, Xian Y, Wang D, Mao L, Jin H, Hu B (2020) Acute cerebrovascular disease following COVID-19: a single center, retrospective, observational study. Stroke Vasc Neurol 5(3):279-284. https://doi.org/10.1136/svn2020-000431

18. Makda A, Kumar S, Kumar A, Kumar V, Rizwan A (2020) The Frequency of Neurological Symptoms in COVID-19 Patients at a Tertiary Care Hospital in Pakistan. Cureus 12(9):e10360. https:// doi.org/10.7759/cureus. 10360

19. Piazza G, Campia U, Hurwitz S, Snyder JE, Rizzo SM, Pfeferman MB, Morrison RB, Leiva O, Fanikos J, Nauffal V, Almarzooq Z, Goldhaber SZ (2020) Registry of arterial and venous thromboembolic complications in patients with COVID-19. J Am Coll Cardiol 76(18):2060-2072. https://doi.org/10.1016/j.jacc.2020.08.070

20. Merkler AE, Parikh NS, Mir S, Gupta A, Kamel H, Lin E, Lantos J, Schenck EJ, Goyal P, Bruce SS, Kahan J, Lansdale KN, LeMoss NM, Murthy SB, Stieg PE, Fink ME, Iadecola C, Segal AZ, Cusick M, Campion TR Jr, Diaz I, Zhang C, Navi BB (2020) Risk of ischemic stroke in patients with coronavirus disease 2019 (COVID-19) vs patients with influenza. JAMA Neurol 77:1366. https://doi.org/10.1001/jamaneurol.2020.2730

21. Lodigiani C, Iapichino G, Carenzo L, Cecconi M, Ferrazzi P, Sebastian T, Kucher N, Studt JD, Sacco C, Bertuzzi A, Sandri MT, Barco S, Humanitas C-TF (2020) Venous and arterial thromboembolic complications in COVID-19 patients admitted to an academic hospital in Milan, Italy. Thromb Res 191:9-14. https:// doi.org/10.1016/j.thromres.2020.04.024

22. Merkler AE, Parikh NS, Mir S, Gupta A, Kamel H, Lin E, Lantos J, Schenck EJ, Goyal P, Bruce SS, Kahan J, Lansdale KN, LeMoss NM, Murthy SB, Stieg PE, Fink ME, Iadecola C, Segal AZ, Campion TR Jr, Diaz I, Zhang C, Navi BB (2020) Risk of ischemic stroke in patients with Covid-19 versus patients with influenza. medRxiv. https://doi.org/10.1101/2020.05.18.20105494

23. Boehme AK, Luna J, Kulick ER, Kamel H, Elkind MSV (2018) Influenza-like illness as a trigger for ischemic stroke. Ann Clin Transl Neurol 5(4):456-463. https://doi.org/10.1002/acn3.545

24. Smeeth L, Thomas SL, Hall AJ, Hubbard R, Farrington P, Vallance P (2004) Risk of myocardial infarction and stroke after acute infection or vaccination. N Engl J Med 351(25):2611-2618. https://doi.org/10.1056/NEJMoa041747

25. Ranucci M, Ballotta A, Di Dedda U, Bayshnikova E, Dei Poli M, Resta M, Falco M, Albano G, Menicanti L (2020) The procoagulant pattern of patients with COVID-19 acute respiratory distress syndrome. J Thromb Haemost 18(7):1747-1751. https://doi.org/10. $1111 /$ jth. 14854

26. Violi F, Pastori D, Cangemi R, Pignatelli P, Loffredo L (2020) Hypercoagulation and antithrombotic treatment in coronavirus 2019: a new challenge. Thromb Haemost 120(6):949-956. https:// doi.org/10.1055/s-0040-1710317

27. Connors JM, Levy JH (2020) Thromboinflammation and the hypercoagulability of COVID-19. J Thromb Haemost 18(7):15591561. https://doi.org/10.1111/jth.14849

28. Naeimi R, Ghasemi-Kasman M (2020) Update on cerebrovascular manifestations of COVID-19. Neurol Sci 41(12):3423-3435. https://doi.org/10.1007/s10072-020-04837-0

29. Huang C, Wang Y, Li X, Ren L, Zhao J, Hu Y, Zhang L, Fan G, Xu J, Gu X, Cheng Z, Yu T, Xia J, Wei Y, Wu W, Xie X, Yin W, Li H, Liu M, Xiao Y, Gao H, Guo L, Xie J, Wang G, Jiang R, Gao Z, Jin Q, Wang J, Cao B (2020) Clinical features of patients infected with 2019 novel coronavirus in Wuhan, China. Lancet 395(10223):497506. https://doi.org/10.1016/S0140-6736(20)30183-5

30. Guan WJ, Ni ZY, Hu Y, Liang WH, Ou CQ, He JX, Liu L, Shan H, Lei CL, Hui DSC, Du B, Li LJ, Zeng G, Yuen KY, Chen RC, Tang CL, Wang T, Chen PY, Xiang J, Li SY, Wang JL, Liang ZJ, Peng YX, Wei L, Liu Y, Hu YH, Peng P, Wang JM, Liu JY, Chen Z, Li G, Zheng ZJ, Qiu SQ, Luo J, Ye CJ, Zhu SY, Zhong NS, China Medical Treatment Expert Group for C (2020) Clinical characteristics of coronavirus disease 2019 in China. N Engl J Med 382(18): 1708-1720. https://doi.org/10.1056/NEJMoa2002032

31. Zhou F, Yu T, Du R, Fan G, Liu Y, Liu Z, Xiang J, Wang Y, Song B, Gu X, Guan L, Wei Y, Li H, Wu X, Xu J, Tu S, Zhang Y, Chen H, Cao B (2020) Clinical course and risk factors for mortality of adult inpatients with COVID-19 in Wuhan, China: a retrospective cohort study. Lancet 395(10229):1054-1062. https://doi.org/10. 1016/S0140-6736(20)30566-3

32. Lippi G, Cervellin G, Casagranda I, Morelli B, Testa S, Tripodi A (2014) D-dimer testing for suspected venous thromboembolism in the emergency department. Consensus document of AcEMC, CISMEL, SIBioC, and SIMeL. Clin Chem Lab Med 52(5):621628. https://doi.org/10.1515/cclm-2013-0706

33. Petrilli CM, Jones SA, Yang J, Rajagopalan H, O'Donnell L, Chernyak Y, Tobin KA, Cerfolio RJ, Francois F, Horwitz LI (2020) Factors associated with hospital admission and critical illness among 5279 people with coronavirus disease 2019 in New York City: prospective cohort study. BMJ 369:m1966. https://doi.org/10.1136/bmj.m1966

34. Madsen TE, Khoury J, Cadena R, Adeoye O, Alwell KA, Moomaw CJ, McDonough E, Flaherty ML, Ferioli S, Woo D, Khatri P, Broderick JP, Kissela BM, Kleindorfer D (2016) Potentially missed diagnosis of ischemic stroke in the emergency department in the Greater Cincinnati/Northern Kentucky Stroke Study. Acad Emerg Med 23(10):1128-1135. https://doi.org/10.1111/acem.13029

35. Del Rio C, Malani PN (2020) COVID-19-new insights on a rapidly changing epidemic. JAMA 323(14):1339-1340. https://doi.org/10. 1001/jama.2020.3072

36. Morelli N, Rota E, Terracciano C, Immovilli P, Spallazzi M, Colombi D, Zaino D, Michieletti E, Guidetti D (2020) The baffling case of ischemic stroke disappearance from the casualty department in the COVID-19 Era. Eur Neurol 83(2):213-215. https://doi.org/ $10.1159 / 000507666$

Publisher's note Springer Nature remains neutral with regard to jurisdictional claims in published maps and institutional affiliations. 